\title{
The Effects of an Experimental Training Program for Teachers of Vocational English Using Concentrated Language Encounter Instructional Processes and Reciprocal Peer Teaching Strategies
}

\author{
Saowalak Rattanavich ${ }^{1}$ \\ ${ }^{1}$ School of Education, Srinakharinwirot University, Bangkok, Thailand \\ Corresponding: Saowalak Rattanavich, School of Education, Srinakharinwirot University, Bangkok, Thailand. \\ Tel: 66-8181-24862. E-mail: s_rattanavich@hotmail.com
}

Received: September 20, 2017 Accepted: November 1, $2017 \quad$ Online Published: November 3, 2017

doi: 10.5539/elt.v10n12p58

URL: http://doi.org/10.5539/elt.v10n12p58

\begin{abstract}
This experimental study aims to investigate the effects of three vocational English classes, each one academic semester in duration, and using the concentrated language encounter approach and reciprocal peer teaching strategies. This study employed a time-series design with one pre-experiment and two post-experiments. Discourse and frequency analysis were performed in relation to the teachers' English language teaching performance and their students' English listening and speaking performance. The students' reading and writing tests were subjected to analysis of variance with repeated measures, including plotted line graphs. The results revealed a tendency among the teachers and students to increase the frequency of their English language use in each class. The quality of the students' reading and writing were also significantly improved. All teachers expressed positive opinions about the experimental teaching treatment and its effect on the students English.
\end{abstract}

Keywords: concentrated language encounter instructional process; reciprocal peer teaching; vocational English

\section{Introduction}

\subsection{Background and Problem Statement}

As an international language used in most parts of the world, English is significant in terms of communication, employment, and access to knowledge. Moreover, English proficiency is increasing associated with economic capacity building throughout the ASEAN community. According to the 2013 Education First English Proficiency Index, Thailand ranked 55 out of 60 countries in terms of English proficiency (Education First, 2013). Top ranking countries all tended to be high income countries, such as Sweden, Norway, and Netherlands (Education First, 2013).

According to a report commissioned by the Thailand Ministry of Education (2014), English language instruction in Thailand is severely hampered by a lack of quality English language teachers and the inability of students to use English. According to this same report, 52\% of English language teachers were themselves ranked as improving in terms of their English proficiency. A further $80 \%$ of primary school teachers lacked proper teaching qualifications and had limited knowledge of curriculum development, lesson planning, and the construction of teaching materials. Most teachers were overloaded, lacked adequate self-learning resources, and their social roles did not support their English learning. Fifty percent of students failed in every English language class and were ranked as improving. In addition, the students had negative attitudes about learning English because the instructions given to them were not compatible with their basic knowledge skills. The learning skills were not integrated into the wider curriculum and there were insufficient opportunities for students to practice using English.

To overcome the aforementioned problems, the Thailand Ministry of Education (2014) streamlined the introduction of a range of new policies to reform English language instruction across all educational levels, especially in basic and vocational education. The strategic plan prioritizes vocational English in order to elevate the Thai population's English language use to international standards. The Common European Framework of Reference for Language (CEFR) has been used to provide the conceptual framework for English language instruction in Thailand to elevate the English teaching competencies of teachers in areas relevant to their students' learning processes and communicative skills, including their ability to use media and information technology as 
tools for developing the English language skills of teachers and students.

Improving teacher education for teachers of English is essential for meeting the requirements of the Thai government's strategic plan for English instructional reform. Consequently, research on an appropriate teacher education models for teachers of vocational English is necessary in order to help problem-solve solutions for elevating level of English language usage among people for their future occupations.

\section{Review of the Literature}

\subsection{Theoretical Framework of Reciprocal Peer Teaching}

Reciprocal peer teaching is an instructional strategy used for cooperative learning and has been well-received worldwide. Through the use of reciprocal peer teaching strategies, students have opportunities to share information and exchange ideas while learning. Independently, helping other students learn facilitates the learning process via the exchange of ideas and by encouraging students to take a more proactive approach toward learning activities. Students are able to present their feedback and have self-evaluation while taking turns teaching and learning themselves as teachers and students. It is a natural learning process in which students have more opportunities to use their own thinking processes, skills, and learning experiences for acquiring information and sharing knowledge. Cooperative learning between teachers and students is an ongoing process that constitutes effective active learning (Allen, 2003; Oczkus, 2003).

Vygotsky's zone of proximal development theory concerning social construction activities (e.g., dialog, knowledge development, thinking, learning review, and scaffolding) suggests that learning interactions among students can occur as effectively among friends and the teacher provides a theoretical framework for reciprocal peer teaching (Vygotsky, 1978, cited in Gallaway, 2001). In scaffolding, the teacher allows the students to do as much as they can to complete the learning task, with the teacher helping student by providing assistance whenever the student cannot complete the learning task themselves. Over time, as students learn to control the pace of task, the teacher allows the student to assume greater control over the activity. Eventually, the student should be able to complete the entire task themselves without the teacher's assistance (Gray, 2007).

For reciprocal peer teaching to be effective, the teacher must prepare the learning model for students in order to help them develop precision in their learning. This can be achieved by allowing students to take turns being the teacher and the student. The reciprocal peer teaching model usually has four continuous steps: predicting, questioning, clarifying, and summarizing. The teacher uses scaffolding techniques as necessary to assist students to achieve while learning. Suggestions and reinforcement are used simultaneously with scaffolding techniques. The effects of reciprocal peer teaching can be further enhanced by exploiting the nature of group dynamics; separating students into groups of 4-6 to ensure that they have an equal opportunity to practice learning-teaching activities. An effective model of reciprocal peer teaching entails matching student couples to work and take turns teaching each other. Both students take turns being the teacher and the student, exchanging their roles to help explain to the other their understanding of the learning text or teaching content. The students can continuously summarize, evaluate their activities, their friends' comments, explanations, and reasons. These meaningful learning activities can extend students' analytical thinking skills and develop long-term learning potential. The more the students experience analytical thinking skills for themselves, the more sophisticated their repertoire of learning skills becomes (B. W. Griffin \& M. M. Griffin, 1997; Goto \& Schneider, 2010).

\subsection{Concentrated Language Encounter Teaching Approach}

Much like reciprocal peer teaching requires well-prepared steps before actual teaching-learning activities, an effective model of teaching vocational English is also required to be matched with the activity-based context. In other words, the learning text should be carefully chosen to suit the language contextual resources.

Originally, concentrated language encounter (CLE) teaching was developed by Gray (2014) as a sequence of lessons that focused on the production of a specific text, which was carefully chosen prior to teaching. Systematically teaching in the CLE sequence supports the development of the students' ability to control, understand, and deconstruct the target text. This target text is the product of an extended instructional text intended for exploration by students with the help of the teacher, who uses scaffolding to facilitate learning. Based on the work of Halliday (1975), Gray (2014) defined the text as "a body of language that is designed to do a job in a particular context." The texts in Halliday's (1975) earlier studies were taxonomies around the following three general categories:

"Transactional texts (working texts, such as forms, notices, and signs);

Factual texts (recounts, procedures, explanations, descriptions, reports, and arguments); 
Literary texts (recounts, narratives, stories for children, poetry, legends, and fables)."

The nature of the teaching and learning negotiation process is the key element in the CLE approach, in which the teacher and student both take an active part in negotiating the student's learning. The CLE lesson sequence is based on the work of Vygotsky (1978) and on research involving parent-child language and literacy development, emphasising the notion of scaffolding as particularly important. In terms set forth by Gray (2007), scaffolding describes the adult's role in determining what is to be learned by the children, as well as how the learning will be negotiated between them. Whereas the teaching and learning activities in CLE are experiential, learning is contextualised through real world activities and experiences.

A central concern of the CLE teaching process is in maximising the practical use of the language around real life contexts. Scaffolding in teaching-learning situations allows for the development of a thinking framework in the learner, which is appropriate for allowing the learner to respond and speak in whichever context directly affects their everyday lives. The CLE learning process emphasises thinking about language use, which is modelled on the presentation of the material explored in the text and activity-based units, and is progressively acquired though the scaffolding of instructions in each phase. Students continually make connections between thinking about language and using language in relevant contexts, eventually being able to transfer their thoughts into both spoken and written language, and into non-verbal communication (e.g., facial expressions), thereby making direct improvements in the quality of their everyday lives (Rattanavich, 2015).

The CLE program is built around three stages of literacy development, as summarised by Rattanavich (2015):

"Stage 1 (for less experienced or beginner readers)

The objective is to create enthusiasm in the learner for reading and writing simple texts of various kinds. The emphasis is on enjoying reading and writing, and on becoming successful in spoken and written language. Learners are taught how to learn and to enjoy the learning process, thereby facilitating self-improvement.

Stage 2 (for learners who are able to read and write simple texts independently)

This stage is aimed at widening the range of texts or genres that the learner can read and write in their everyday life. It includes a range of effective reading and writing techniques.

Stage 3 (for advanced learners)

Emphasises learning through reading and writing. The overall objective of this stage is to provide all the literacy skills that learners will ever need for when they leave school and the learning skills that they will need at higher levels."

CLE programs have been categorised into four types of literacy programs to better organise curriculum development planning, the training of key personnel, the development of learning materials, and research studies. These four types are: (a) formal or school-based programs; (b) informal education programs (e.g., adult literacy and street children); (c) special education programs (e.g., for disabled students); and (d) ethnic group programs (Rattanavich, 2015; Walker et al., 1992).

Research on CLE teaching models in Thailand indicates positive results for learners' language development and personal development. The models have been replicated all throughout Thailand, as well as other countries, including Turkey, India, Egypt, South Africa, Brazil, Malaysia, Laos, Nepal, Bangladesh, and the Philippines (Rattanavich, 2003; Rotary International, 2009).

\subsection{Development of Curriculum Materials and a Teacher Program in CLE}

Following the successful development of CLE literacy programs in Thailand (Rattanavich et al., 1993), two strategies have been developed: (a) basic literacy curriculum materials and (b) a teacher development program. The texts used in the program have been planned based on a genre -based approach, because genres or text types are derived from the cultural context and the context in which people use a spoken or written language. Genres have their own characteristic shapes-a 'schematic structure'-represented by the spoken or written organisational structure of a language used by people when conveying meaning to a listener or reader for a particular purpose. As different genres have different purposes (e.g., recounting, reporting, discussing, explaining, narrating, exposing, interviewing, observing, etc.), a pattern of linguistic features develops for conveying spoken or written messages in different situations. To enable students to feel more at ease while learning how to think about and organise their thoughts into comprehensible and grammatically concise oral or written texts, the teacher should be trained in essential genre analysis and equipped with the resources necessary to better plan the text as a language model. The teacher must also consider his or her own thoughts in relation to the text to be used in the lesson and the context in which students should engage with the text. Once students have established a familiarity 
with the text (i.e., reading and talking about it), they can develop various aspects of the language used, such as spelling, handwriting systems, and the organisation of written sentences. The content of the text that the student develops is chosen on the basis of whatever content is most likely going to improve their career prospects and enjoyment in life (Christie, 2010; Rattanavich, 1997; Rattanavich et al., 1993).

Based on the original CLE research studies implemented in Thailand, introduced by Rattanavich (2015), the genres used to develop the texts in the CLE program can be flexible, based on three objectives: (a) reading for entertainment, (b) reading to do, and (c) reading to learn. The texts are planned into two types: (a) an activity-based unit for the procedural genres or 'how to' texts, and (b) a text-based unit for other genres used in CLE teaching. When teaching vocational skills in a CLE language class in which most texts are procedural genres, activity-based texts are usually planned. The steps/phases of instruction in CLE in activity-based units are arranged as follows:

a. Sharing the structured experience (introducing the materials and demonstrating how to perform the activity, with a clear, slow, step-by-step oral explanation).

b. Reconstructing the experience (asking students to orally review the materials and the steps on how to perform the activity before allowing them to do the activity on their own, either individually or in small groups).

c. Negotiating a group text.

d. Making a big book.

e. Language activities through games (the teacher can adapt the language activities to suit the students' age groups and abilities to focus on smaller units of the language, such as pronunciation, idioms, more sophisticated reading activities, writing with different text types or genres, spelling, grammatical points, etc.).

In the text-based unit, all teaching steps are the same except for Steps a and b. The teacher usually starts Step a by reading the text with students and then goes on to Step b by asking the students to recall and discuss the text, and to role-play the content.

\subsection{Objectives of the Study}

The objective of this study is to investigate the effects of the experimental program using the CLE instructional process and students' reciprocal peer teaching strategies with both teachers and students in each class as follows:

1) the development of the teacher's English language use in class,

2) the development of the teacher's English speaking by using scaffolding techniques in class,

3) the teacher's opinions about the instructional activities used in class, as well as their students' learning development and attitudes,

4) the students' development of English listening and speaking skills in class, and

5) the students' development in vocational English reading and writing performance.

\subsection{Conceptual Framework of the Study}

Independent Variable

CLE learning process using students' reciprocal peer teaching strategies

\section{Dependent Variables}

Teachers' classroom English language use

Teachers' English speaking by using scaffolding techniques

Students' English listening- speaking in class

Students' development in reading and writing

Figure 1. Conceptual framework of the study

\subsection{Hypothesis of the Study}

Based on the research objectives and the literature review, the following hypotheses were formulated for this study:

Hypothesis 1.The teacher's frequency of English language use in class after the experiment will increase, as indicated by the line graph. 
Hypothesis 2. The teacher's frequency of speaking English through the use of scaffolding techniques in class will increase, as indicated by the line graph, after the experiment.

Hypothesis 3. The teacher in each class will expresses positive comments about the instructional activities, as well as the students' learning development and attitudes, through the CLE process of learning using reciprocal peer teaching strategies.

Hypothesis 4.The students in each vocational English class will show a tendency to speak and listen more frequently in English as indicated by the line graph.

Hypothesis 5. The students' post-experimental reading and writing scores will shows significant improvement as compared to pre-experiment scores.

\subsection{Research Questions}

According to the aforementioned hypotheses, the following research questions have been developed:

Question 1. Does the tendency, shown by the line graph, indicate better overall use of the teacher's English language after the experiment?

Question 2. Does the tendency, shown by the line graph, indicate better overall use of the teacher's English speaking through the use of scaffolding techniques after the experiment?

Question 3. Does the teacher of each vocational English class express mostly positive comments/opinions regarding the CLE learning process using reciprocal peer teaching strategies, as well as students' learning development and attitudes?

Question 4. Does the tendency, shown by the line graph, indicate overall better student listening and speaking performance in each class after the experiment?

Question 5. Do the students in each experimental class improve their reading and writing performance after the experiment?

\section{Methodology}

\subsection{Research Design and Sampling}

A quasi-experimental time-series design was used in the study.

$\begin{array}{lllll}\mathrm{T} 1 & \mathrm{X} & \mathrm{T} 2 & \mathrm{X} & \mathrm{T} 3\end{array}$

$\mathrm{X}=$ Experimental group treatment

$\mathrm{T} 1=$ Pre-test

$\mathrm{T} 2=$ Post-test 1

$\mathrm{T} 3=$ Post-test 2

Three second-year vocational English teachers in three vocational classes (i.e., sales, print media, and secretarial work) at SIBA College (Bangkok, Thailand) were purposively sampled during the second semester of the 2015 academic year (November, 2015-March, 2016). Learners received 3 teaching hours per unit per week over 4 months. Teachers were pre-tested during the first week of the semester and given one week orientation and training to the experimental treatment. Teachers then had 12 weeks of actual teaching (i.e. 36 teaching hours with three teaching units/class/week). The teachers taught six teaching units before having their first post-test. After the first post-test, they continued with another six teaching units before having the second post-test.

\subsection{Research Instruments}

For this study, a teacher training program was planned for the vocational English class of SIBA College in Bangkok. Three classes were planned for different occupational programs, including sales, print media, and secretarial work. The teaching texts for vocational English language use were tailored for each occupational program in terms of context and language use.

The CLE instructional process with reciprocal peer teaching strategies was broken down into five steps/phases of instruction as follows:

Step 1. The teacher introduces each material or functional content and demonstrates how to perform the activity with a clear, slow, step-by-step oral explanation. For example, answering a telephone call and communicating with customers as a secretary; showing the learner a picture of a historic place and asking them to role play being a tour guide, etc. 
Step 2. Asking students to orally review the materials used or the sequence of the activities before allowing them to do the activity on their own or in small groups.

Separating students into groups of four and taking turns at being the teacher and student in Steps 1 and 2 helps the students to learn to perform the activities according to the steps introduced by the teacher.

Step 3. The teacher demonstrates how to negotiate a group text between the teacher and student, and then sorts the students into group of four to take turns negotiating the text and writing on the draft paper.

Step 4. Each group of students makes their group book by copying the text from the draft paper in Step 3 and decorating their group book as they see fit. In each group, the students take turns at being the teacher to check for mistakes in the students' reading and writing.

Step 5. Each group of students uses their group book as a resource to play language games, such as spelling games, reading games, sentence writing games, etc.

Each student takes turns at being the teacher and the students explain and lead their group in playing each of the games one at a time.

The research instruments employed for data collection included 12 trial-out teaching units of lesson plans for each class based on the CLE learning process using reciprocal peer teaching strategies introduced and trained by the researcher as the treatment in the study according to the steps above. The observations of actual classroom teaching-learning situations were recorded by video in the pre-test or pre-experiment sessions and every 6-week for post-test 1 (i.e., post-experiment 1) and post-test 2 (i.e., post-experiment 2). The standardized SIBA College close-test and multiple choice test of reading comprehension and occupational knowledge skills (reliability 0.93), and an essay writing test set in a particular occupational context (reliability 0.88 , calculated by Cronbach's Alpha Coefficient) were also administered to the three classes of students at pre-test, post-test 1 , and post-test 2 intervals. After the experiment, the teachers were administered an open-ended questionnaire to solicit their opinions regarding the instructional activities used in class, as well as the students' learning and attitudes.

\subsection{Treatment of the Study}

After the pre-test, the three sampled teachers were given 1-week of orientation and training on CLE learning processes using reciprocal peer teaching strategies. During this period, the researcher demonstrated the process of drafting lesson plans and the five teaching steps as indicated in section 2.4 of the literature review. The actual teaching of all three teachers through the CLE learning process using reciprocal peer teaching strategies was conducted over the course of 3 hours per week with 36 teaching unit hours of lesson plans tested and approved by the researcher. Post-tests 1 and 2 were administered to the students every six weeks.

\subsection{Data Analysis}

Hypotheses 1 and 2 were investigated through discourse and frequency analysis of the teachers' use of spoken English in each class and use of spoken English for scaffolding. The line graphs, indicating the overall pattern of English language usage by the teachers while teaching and their use of scaffolding, are submitted as indicating the overall results for each hypothesis.

The three sampled teachers' classroom observations at pre-test and the two post-test intervals were transcribed into separate discourse scripts. The subsequent teacher and student discourses for each class were analysed using frequency analysis of the teacher's English language use. English language use was scored for each of the following teaching behaviours: warm up, explain/lecture, direct/command, demonstrate, questions by the teacher, answers by the teacher, criticize/give feedback, using English through visual/blackboard, encourage students, read materials, drill, and repeat/review. The discourse analysis of the teachers' use of English while scaffolding was focused on the frequency of English usage while initiating/questioning/giving examples to stimulate conversation, leading by some words/sentences to support communication/interaction, encouraging student interaction, and repeating students' words/sentences to facilitate interaction.

Hypothesis 3 was investigated by summarizing the teacher's comments (per the questionnaires) in relation to the instructions and activities (i.e. experimental treatment) used in class and the effects of those instructions on the students' learning development and attitudes. This was important in terms of finding out what the teachers thought about the CLE instructional process using reciprocal peer teaching strategies and the students' learning attitudes, and was helpful in terms of guiding improvement after the experiment.

Hypothesis 4 was investigated by analysing the students' discourse, transcribed from video tape, based on the actual teaching in the experiment, and by analysing the frequency of students' listening and speaking (i.e., communication/interaction), which involves following/reacting to directions, answering questions, asking 
questions, initiating ideas/comments/others for communication, and giving feedback/interacting (with a friend/among friends and with the teacher). A line graph was plotted to represent the overall tendency of the students in relation to listening and speaking English in class.

Hypothesis 5 was tested by calculating the students' pre-test and two post-test reading and writing scores using analysis of variance with repeated measures and multiple comparisons using the Holm-Bonferroni method at the 0.05 level of confidence and the effect size indicated by way of a line graph.

\section{Results of the Study}

Question 1. Does the tendency, shown by the line graph, indicate better overall use of the teacher's English language after the experiment?

The data presented in Table 1 shows the frequency of each teacher's use of the English language in class pre-test, and at post-test1, and post-test 2 intervals. In Figures 1, 2, and 3, the line graphs indicate an increasing tendency among the three teachers to use English in class between pre-experiment and post-experiment 1 and 2 intervals.

Table 1. Frequency analysis of three teachers' English language performance in the experiment

\begin{tabular}{llllllllll}
\hline Teacher's English Language Use & \multicolumn{3}{c}{ Pre-Experimental } & \multicolumn{3}{c}{ Post-Experimental 1} & \multicolumn{3}{c}{ Post-Experimental 2 } \\
& $\mathrm{T} 1$ & $\mathrm{~T} 2$ & $\mathrm{~T} 3$ & $\mathrm{~T} 1$ & $\mathrm{~T} 2$ & $\mathrm{~T} 3$ & $\mathrm{~T} 1$ & $\mathrm{~T} 2$ & $\mathrm{~T} 3$ \\
\hline 1. Warm up & - & 1 & - & - & 1 & 1 & 1 & 1 & 1 \\
2. Explain/Lecture & 4 & 12 & 3 & 11 & 16 & 11 & 17 & 15 & 6 \\
3. Direct/Command & 17 & 19 & 12 & 23 & 33 & 7 & 32 & 23 & 12 \\
4. Demonstration & 1 & - & 4 & - & - & 4 & 33 & - & 8 \\
5. Question & 31 & 50 & 17 & 82 & 34 & 9 & 85 & 40 & 33 \\
6. Answer & 13 & 4 & 5 & 49 & 12 & 4 & 20 & 3 & 5 \\
7. Criticize/Give Feedback & 13 & - & 25 & 23 & 27 & - & 29 & 45 & 15 \\
8. Through & - & 10 & 5 & - & - & - & 5 & - & - \\
Audio-Visual/Blackboard & & & & & & & & & \\
9. Encourage & 2 & 5 & 1 & 3 & 6 & - & 3 & 10 & - \\
10. Read (Material) & - & 1 & 1 & - & - & - & - & - & - \\
11. Drill & - & 3 & 1 & - & - & - & 1 & 7 & 30 \\
12. Repeat/Review & 4 & 7 & 12 & 7 & 20 & 5 & 21 & 7 & 35 \\
\hline Total & 85 & 112 & 86 & 198 & 149 & 41 & 227 & 151 & 145 \\
\hline
\end{tabular}

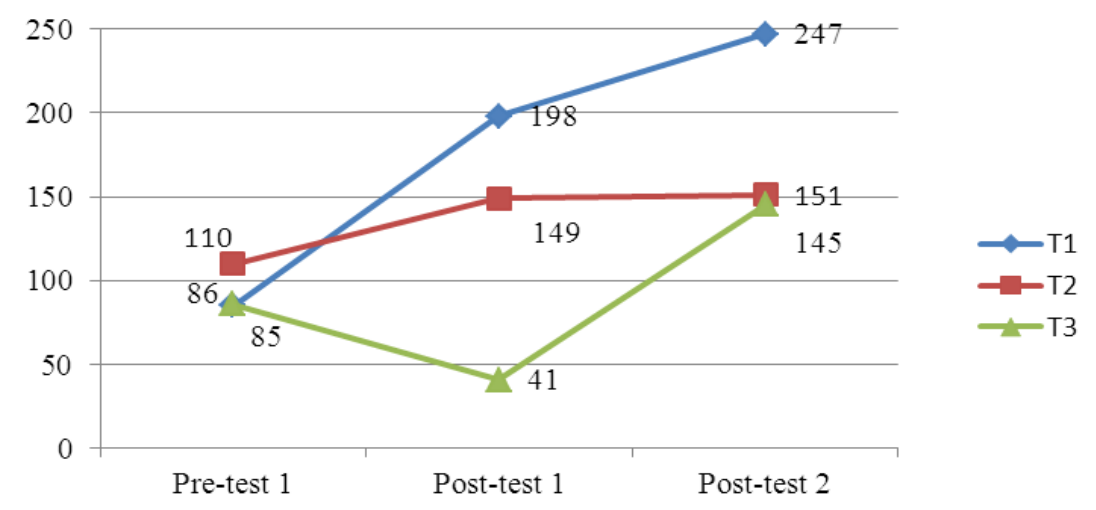

Figure 2. Line graph showing the overall tendency of three teachers' English language performance in the experiment 
Question 2. Does the tendency, shown by the line graph, indicate better overall use of the teacher's English speaking through the use of scaffolding techniques after the experiment?

Table 2 indicates the frequency of English speaking by the three teachers when using scaffolding techniques in class. The line graph in Figure 2 also shows the overall increasing tendency of each of the teachers to speak English when using scaffolding techniques after the experiment.

Table 2. Frequency analysis of the three teachers' English speaking performance for scaffolding techniques in teaching

\begin{tabular}{|c|c|c|c|c|c|c|c|c|c|}
\hline \multirow{2}{*}{$\begin{array}{l}\text { Teachers' English Speaking for } \\
\text { Scaffolding }\end{array}$} & \multicolumn{3}{|c|}{ Pre-Experimental } & \multicolumn{3}{|c|}{ Post-Experimental 1} & \multicolumn{3}{|c|}{ Post-Experimental 2} \\
\hline & $\mathrm{T} 1$ & $\mathrm{~T} 2$ & $\mathrm{~T} 3$ & $\mathrm{~T} 1$ & $\mathrm{~T} 2$ & $\mathrm{~T} 3$ & $\mathrm{~T} 1$ & $\mathrm{~T} 2$ & $\mathrm{~T} 3$ \\
\hline $\begin{array}{l}\text { 1. Initiate/question/give } \\
\text { examples to stimulate } \\
\text { conversation/interaction }\end{array}$ & - & 3 & 10 & 15 & 18 & 4 & 21 & 15 & 7 \\
\hline $\begin{array}{l}\text { 2. Lead by adding } \\
\text { words/sentences to support } \\
\text { communication/interaction }\end{array}$ & 7 & 5 & 4 & 44 & 23 & 5 & 40 & 43 & 55 \\
\hline 3. Encourage & 3 & 1 & 1 & 8 & 6 & - & 15 & 10 & - \\
\hline $\begin{array}{l}\text { 4. Repeat words/sentence of } \\
\text { students to facilitate interaction }\end{array}$ & 3 & 3 & 10 & 9 & 13 & 3 & 21 & 7 & 29 \\
\hline Total & 13 & 12 & 25 & 76 & 60 & 12 & 99 & 75 & 91 \\
\hline
\end{tabular}

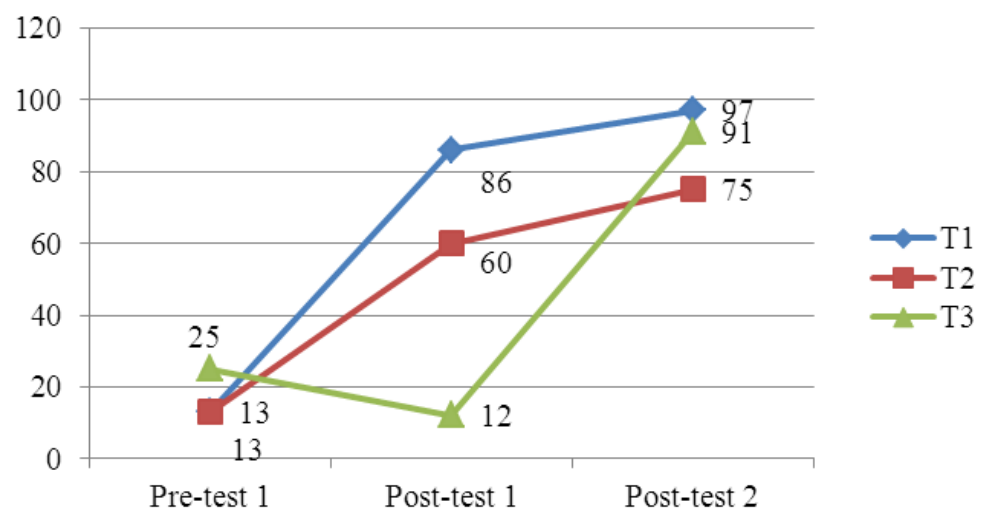

Figure 3. Line graph showing the tendency of the three teachers' English language performance for use of scaffolding techniques in the teaching experiment

Question 3. Does the teacher of each vocational English class express mostly positive comments/opinions regarding the CLE learning process using reciprocal peer teaching strategies, as well as students' learning development and attitudes?

The following summary reports the positive opinions of the three teachers regarding the instructional activities used in classes, as well as their students' learning development and attitudes:

1) Knowledge and Teaching Professional Skills

Teacher A: The instruction used is practical with systematic vocational teaching steps that make it easy for the teacher to implement effectively in class with students.

Teacher B: The instructions are quite easy to follow for each teaching step and are practical for use with the students.

Teacher $C$ : Teaching activities in each teaching step are practical to follow and easy to implementing class with the 
students.

2) Methods and Teaching Techniques

Teacher A: The teaching steps are practical for teaching vocational skills along with English language practice in actual procedural situations. Students have practical learning activities and are encouraged to get involved in exchanging ideas and experiences with friends in reciprocal peer teaching.

Teacher B: The teaching steps are easy to remember and continuously related to the steps of vocational skills required until the end. Students are able to develop their English language use in the real procedural vocational skills. Reciprocal peer teaching helps them to experience more in the content and communication with friends in English.

Teacher $C$ : The learning activities in each teaching step are student-centred, causing the students to become active in the learning experience with their friends and the teacher. Reciprocal peer teaching through CLE procedural learning make students feel at ease to understand the meaning of vocabularies and idioms in the real situations and have more confidence in communication in English.

3) Evaluation/Assessment of Teaching-Learning

Teacher A: Activities in each teaching steps can be used as self-evaluation for individual students. Each student can keep their own pace in learning with friends under the teacher's help.

Teacher B: Teaching steps can help students and the teacher evaluate their accomplishments and behavioural learning objectives by students' group and individual tasks.

Teacher $C$ : Students are able to evaluate their learning in each teaching step activities of task analysis and assignments under the teacher's supervision and friends both in a group and individually.

4) Psychological Application

Teacher A: All of the teaching steps help to ground students; making them feel more secure and self-confident, bolder in their expressions and involvement in active while of sharing their experiences and cooperating in group working process. Activities are interesting and often rely on group dynamics.

Teacher B: Students enjoy sharing the activities in each step among their friends. They can develop their feeling of confidence and feel secure getting involved in learning and communication in English under the help of their teachers and friends.

Teacher $C$ : The steps of teaching can help the students share their experiences and to help one another in learning. The students feel motivated and it is easy for them to learn how to listen, speak, read, and write with the teacher's use of scaffolding and the students' cooperation.

\section{5) Learning Materials}

Teacher A: Students have opportunities to select learning materials they prefer under the teacher's assistance and support. The materials are basically easy to find, such as draft paper, colour pencil/magic pens, blackboard and chalk, laptop and LCD equipment, flip charts, etc.

Teacher B: The materials are simple, authentic things in actual vocational skills training situations. Students are acquainted with those via their learning and it is easy for them to remember them in English.

Teacher $C$ : The teaching materials are easily prepared and less expensive, such as draft paper, magic pens, and flip charts. The internet service is also effective enough for all students to use, in and outside class activities.

6) Classroom Management and Learning Atmosphere

Teacher A: Cooperative active learning always happens in class with different group learning styles, such as pair-work activities, individual learning, whole class discussions, and small group activities.

Teacher B: Student-centred learning is used for classroom management. Group learning processes are usually seen in class through demonstrations, discussions, activity participation, and creative learning construction. The learning atmosphere among students, under the teacher's supervision and assistance, is enjoyable.

Teacher C: All kinds of language activities can be applied in class and outside to create a more realistic vocational skill training situation. Group activities and individual working assignments can be done in constructively so as to harness the students' enthusiasm.

Question 4. Does the tendency, shown by the line graph, Indicate overall better student listening and speaking performance in each class after the experiment? 
Table 3 details the frequency of students listening and speaking in English in each experimental group. The line graph in Figure 3 shows the increasing tendency of the students English listening and speaking performance in each experimental class after the experiment.

Table 3. Frequency analysis of students' English listening and speaking in three different classes in the experimental process

\begin{tabular}{|c|c|c|c|c|c|c|c|c|c|}
\hline \multirow[t]{2}{*}{$\begin{array}{l}\text { Students' Listing \& Speaking in } \\
\text { Class for Communication }\end{array}$} & \multicolumn{3}{|c|}{$\begin{array}{l}\text { Pre-Experimental } \\
\text { Class A }\end{array}$} & \multicolumn{3}{|c|}{$\begin{array}{l}\text { Post-Experimental } 1 \\
\text { Class B }\end{array}$} & \multicolumn{3}{|c|}{$\begin{array}{l}\text { Post-Experimental } 2 \\
\text { Class C }\end{array}$} \\
\hline & $\mathrm{T} 1$ & $\mathrm{~T} 2$ & $\mathrm{~T} 3$ & $\mathrm{~T} 1$ & $\mathrm{~T} 2$ & $\mathrm{~T} 3$ & $\mathrm{~T} 1$ & $\mathrm{~T} 2$ & T3 \\
\hline 1. Follow/react to directions & - & 4 & - & 5 & 3 & 1 & 1 & 10 & 1 \\
\hline 2. Answer questions & 87 & 45 & 70 & 105 & 53 & 51 & 110 & 103 & 131 \\
\hline 3. Ask questions & 70 & 7 & 28 & 57 & 5 & 11 & 58 & 2 & 12 \\
\hline $\begin{array}{l}\text { 4. Initiate ideas/comments other } \\
\text { for communications }\end{array}$ & 15 & 2 & 5 & 10 & 5 & 9 & 10 & 38 & 30 \\
\hline $\begin{array}{l}\text { 5. Give feedback/interact among } \\
\text { friends and with the teachers }\end{array}$ & - & 2 & 3 & 5 & - & - & 5 & - & 4 \\
\hline Total & 172 & 60 & 106 & 182 & 66 & 72 & 184 & 153 & 178 \\
\hline
\end{tabular}

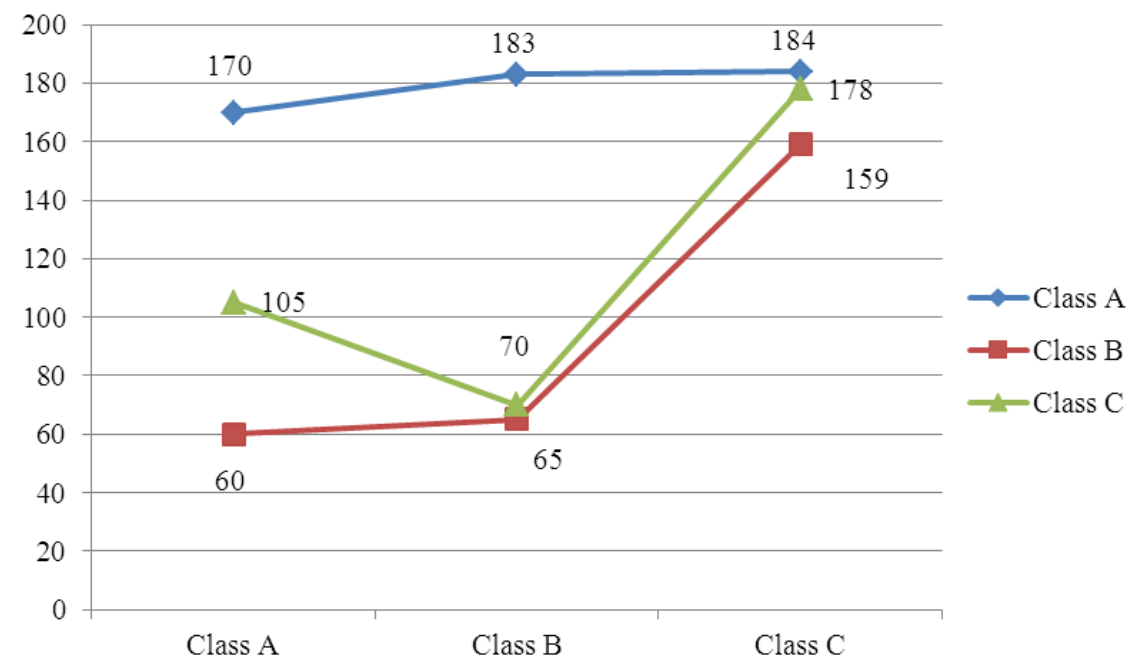

Figure 4. Line graph showing the students' tendency of English listening and speaking performance in the three experimental classes

Question 5. Do the students in each experimental class improve their reading and writing after the experiment?

Tables 4, 5, and 6 detail the results of the analysis of variance with repeated measures of the students' reading and writing scores between pre-test and the two post-tests in Class A (Teacher 1), Class B (Teacher 2), and Class C (Teacher 3). Figures 5, 6, and 7 identify the development of the students' reading and writing in Class A, Class B, and Class $\mathrm{C}$. 
Table 4. Results of ANOVA with Repeated Measures of students' reading and writing performance in experimental class A (Teacher 1)

\begin{tabular}{|c|c|c|c|c|c|}
\hline \multirow{2}{*}{$\mathrm{T} 1$} & \multirow{2}{*}{ Statistic } & \multicolumn{3}{|l|}{ Test } & \multirow{2}{*}{ Univariate Test } \\
\hline & & Pre-test & Post-test 1 & Post-test 2 & \\
\hline \multirow[t]{2}{*}{ Reading } & Mean & 3.27 & 8.40 & 7.97 & \multirow{2}{*}{$\begin{array}{l}\mathrm{MS}_{\mathrm{B}}=1.391 / \mathrm{MS}_{\text {error }}=1.432, \mathrm{~F}= \\
169.817, p \text {-value }<0.01, \text { Partial } \\
\eta^{2}=0.854\end{array}$} \\
\hline & SD & 1.45 & 1.67 & 1.47 & \\
\hline \multirow[t]{2}{*}{ Writing } & Mean & 7.33 & 8.17 & 8.47 & \multirow{2}{*}{$\begin{array}{l}\mathrm{MS}_{\mathrm{B}}=0.264 / \mathrm{MS}_{\text {error }}=0.298, \mathrm{~F}= \\
34.659, p \text {-value }<0.01, \text { Partial } \eta^{2} \\
=0.544\end{array}$} \\
\hline & SD & 0.92 & 0.53 & 0.51 & \\
\hline
\end{tabular}

Table 5. Results of ANOVA with Repeated Measures of students' reading and writing performance in experimental class B (Teacher 2)

\begin{tabular}{|c|c|c|c|c|c|}
\hline \multirow{2}{*}{$\mathrm{T} 2$} & \multirow{2}{*}{ Statistic } & \multicolumn{3}{|l|}{ Test } & \multirow{2}{*}{ Univariate Test } \\
\hline & & Pre-test & Post-test 1 & Post-test 2 & \\
\hline \multirow[t]{2}{*}{ Reading } & Mean & 6.55 & 7.27 & 8.21 & \multirow{2}{*}{$\begin{array}{l}\mathrm{MS}_{\mathrm{B}}=0.489 / \mathrm{MS}_{\text {error }}=0.434, \mathrm{~F} \\
=85.471, p \text {-value }<0.01, \\
\text { Partial } \eta^{2}=0.728\end{array}$} \\
\hline & SD & 0.83 & 0.84 & 0.78 & \\
\hline \multirow[t]{2}{*}{ Writing } & Mean & 6.97 & 8.48 & 9.45 & \multirow{2}{*}{$\begin{array}{l}\mathrm{MS}_{\mathrm{B}}=0.173 / \mathrm{MS}_{\text {error }}=0.480, \mathrm{~F} \\
=101.172, p \text {-value }<0.01, \\
\text { Partial } \eta^{2}=0.771\end{array}$} \\
\hline & SD & 0.84 & 0.63 & 0.62 & \\
\hline
\end{tabular}

Table 6. Results of ANOVA with Repeated Measures of the students' reading and writing performance in experimental class $\mathrm{C}$ (Teacher 3 )

\begin{tabular}{llllll}
\hline T3 & Statistic & $\begin{array}{l}\text { Test } \\
\text { Pre-test }\end{array}$ & Post-test 1 & Post-test 2 & Univariate Test \\
\hline Reading & Mean & 5.83 & 6.67 & 6.90 & $\mathrm{MS}_{\mathrm{B}}=0.993 / \mathrm{MS}_{\text {error }}=1.676$, \\
& SD & 1.12 & 1.37 & 1.47 & $\begin{array}{l}\mathrm{F}=8.150, p \text {-value }<0.01, \text { Partial } \\
\eta^{2}=0.219\end{array}$ \\
\multirow{2}{*}{ Writing } & Mean & 7.68 & 8.52 & 9.52 & $\begin{array}{l}\mathrm{MS}_{\mathrm{B}}=0.224 / \mathrm{MS}_{\text {error }}=0.235, \\
\end{array}$ \\
& SD & 0.60 & 0.57 & 0.68 & $\begin{array}{l}\mathrm{F}=111.553, p \text {-value }<0.01, \\
\text { Partial } \eta^{2}=0.788\end{array}$ \\
\hline
\end{tabular}

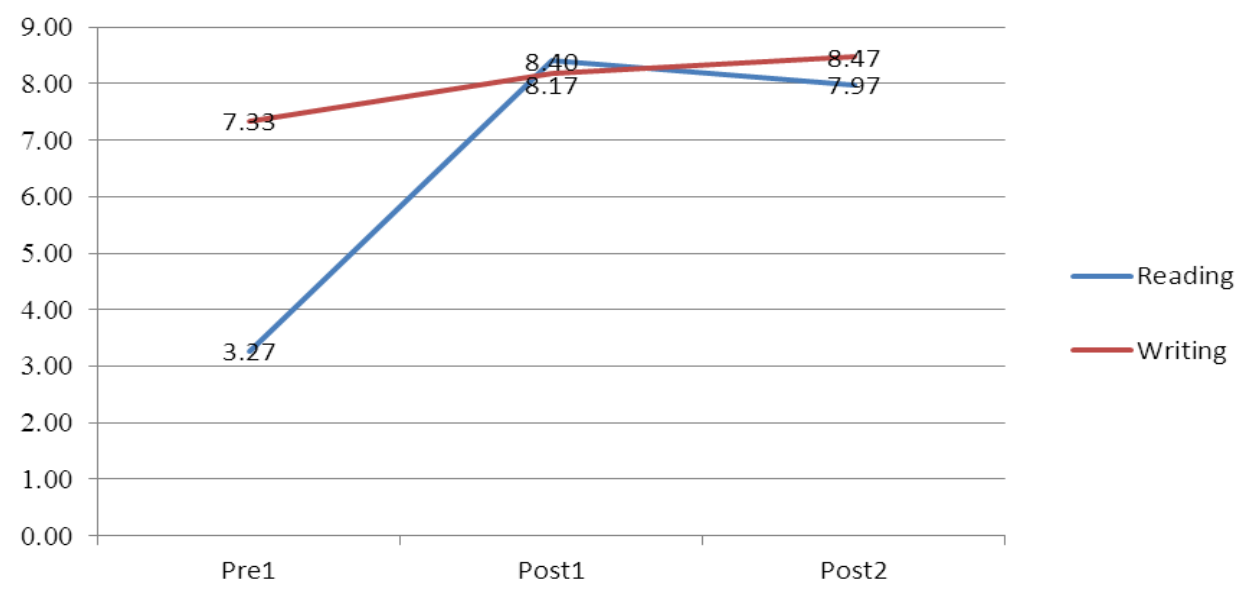

Figure 5. Line graph showing students' development in reading and writing performance in Experimental Class A (Teacher 1) 


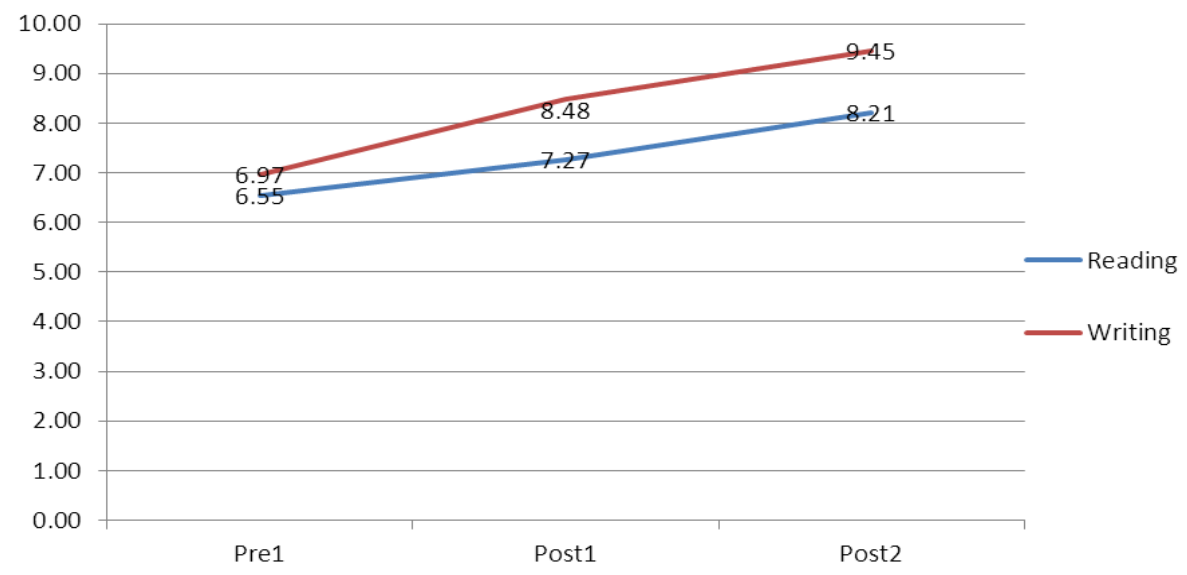

Figure 6. Line graph showing students' development in reading and writing performance in Experimental Class B (Teacher 2)

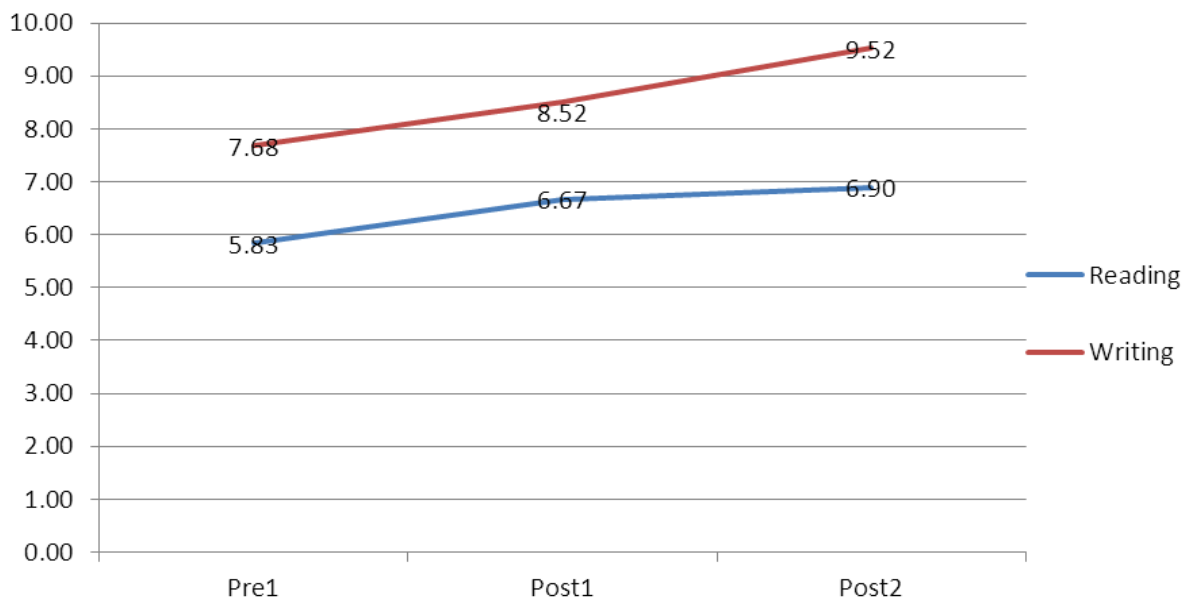

Figure 7. Line graph showing students' development in reading and writing performance in Experimental Class C (Teacher 3)

Tables 4, 5, and 6, as well as Figures 5, 6, and 7, demonstrate that the students in the three experimental occupational class improved their English reading and writing skills by $85 \%$ and $54 \%$ in Class A (sales), $73 \%$ and $77 \%$ in Class B (print media), and by $22 \%$ and $79 \%$ in class C (secretary), respectively.

\section{Discussion of Findings}

The findings from the discourse and frequency analysis, especially the tendency of the teachers' overall English language performance in class (shown by the line graphs), reflect successful results of the increasing performance of the teachers' vocational English in class for instruction through the CLE learning process using reciprocal peer teaching strategies. Through the instructional steps, the teachers were able to develop their own English language skills in teaching demonstration, explanation, questioning, directing, criticizing/giving feedback, and repeating/reviewing the vocational skills of their students. The use of the teachers' scaffolding skills in each step of the CLE learning process successfully assisted the students to perform their verbal and non-verbal language skills for communication about what they needed. The teachers used scaffolding techniques with the students by repeating words or sentences in order to encourage discussion, and also by adding words or sentences to lead the students' thinking, talking about, and negotiating the task of writing in English. Scaffolding is used to help students succeed in listening, speaking, reading, and writing. The supporting evidence, shown by the line graphs of the students' English listening-speaking performance in each class, indicates that students were better able to become involved in listening and speaking activities with their teachers and friends. Consequently, their frequency of listening and speaking in English increased. 
By taking the role of reciprocal peer teaching with their friends in big and small groups and following along with the teachers' stepwise learning process used in this study, the students were afforded more opportunities to practice their English language skills. Alternating roles as teacher and students helped the learners to acquire more vocational skills and increased their confidence in English language use. The learners were excited to take the teacher's role and had prepared their teaching demonstration, explaining, questioning and answering questions, as well as negotiating new learning texts. Overtime, students eventually improved their precision in learning both the content and the communicative language skills from their presentation and active interactional performance among friends by the practical process of reciprocal peer teaching and the scaffolding techniques required in the CLE instructional process under the teachers' supervision and assistance. Their reading and writing performance in relation to their occupational text for each class successfully improved after only 36 teaching hours, as shown by the effect size of the CLE instructional process using reciprocal peer teaching strategies on the students' reading and writing.

The qualitative data on the opinions of the three teachers in the experimental teaching classes indicate agreement with one another and offer support to the research results. The teachers agreed that each teaching step and learning activity process was effective in increasing their English language usage in class, thus helping students learn occupational skills and language use in a meaningful way during cooperative learning situations. The students also improved the precision of their vocational language learning through the reciprocal peer teaching activities as indicated by the statistical report on the effect size of the treatment on the development of reading and writing skills after the experiment.

\section{Conclusions and Recommendations}

This model of vocational English teacher training with the CLE learning-teaching process, plus the effectiveness of reciprocal peer teaching concepts, can be used in teacher education programs for language learning or other areas. The curriculum of each program should be analysed and well-planned to include appropriate learning and teaching materials. The steps of teaching can be planned according to the types of text-units, text- or activity-based, depending on the genres used in learning contexts, such as a text-based unit for recount, report, narrative, discussion, exposition genres and an activity-based program for procedural genres as in the experiment. The numbers of students in each class should be planned to enable the formation of small groups of four or pairs when using reciprocal peer teaching.

\section{Acknowledgements}

The author gratefully acknowledges the Strategic Wisdom and Research Institute of Srinakharinwirot University for the research funding support and SIBA College in Bangkok for facilitating this experimental program. My heartfelt appreciation goes out to the three experimental teachers. The cooperation and assistance of Acharaphan Kansuya, Rewadeee Chantoem, Piyapong Promnon, and Warittha Onto in data collection, data analysis, and the training program is also greatly appreciated.

\section{References}

Allen, S. (2003). An analytic comparison of three models of reading strategy instruction. IRAL: Instructional Review of Applied Linguistics in Language Teaching, 41(4), 319-339. https://doi.org/10.1515/iral.2003.015

Bruner, J. S. (1966). Toward a theory of instructional. Cambridge, Mass: BelKapp Press.

Christie, F. (2010). School discourse: Learning to write across the years of school. London, England: Continuum.

Education First. (2013). EF EPI: EF English proficiency index. Lucerne, Switzerland. Retrieved from http://media2.ef.com/_/ /media/centralefcom/epi/downloads/full-reports/v3/ef-epi-2013-report-en.pdf

Galloway, C. A. (2001). Vygotsky's learning theory. In M. Orey (Ed.), Emerging perspectives on learning, teaching, and technology. Retrieved from $\mathrm{http} / / /$ epltt.coe.uga.edu/index.php?title=Vygotsky\%27s_constructivism

Gray, B. (2007). Accelerating the literacy development of indigenous students. Darwin, Australia: Charles DarwinUniversity Press. https://doi.org/10.1111/j.1440-1754.2007.01047.x

Gray, B. (2014). The Traeger Park project: Developmental outline. Accelerated Literacy Practitioners Association of Australia (ALPAA). Retrieved from http://www.alpaa.com.au/resources/publications

Griffin, B. W., \& Griffin, M. M. (1997). The effects of reciprocal peer tutoring on graduate students'achievement, test anxiety, and academic self-efficacy. The Journal of Experimental Education, 65(3), 197-209. https://doi.org/10.1080/00220973.1997.9943454 
Goto, K., \& Schneider, J. (2010). Learning through teaching: Challenges and opportunities in facilitating student learning in food science and nutrition by using the inter teaching approach. New York, NY: John Wiley \&Sons.

Halliday, M. A. K. (1975). Learning how to mean: Explorations in the development of language. London, England: Edward Arnold. https://doi.org/10.1016/B978-0-12-443701-2.50025-1

Ministry of Education, Thailand. (2014). The guidelines on English language teaching andlearning reforming policy. Bangkok, Thailand: Chamjureeproduct Ltd.

Oczkus, L. D. (2003). Reciprocal teaching at work: Strategies for improving reading comprehension. Newark, DE: International Reading Association.

Rattanavich, S. (2003). A report on the development of Thai language teaching through the concentrated language encounter project, 1988-1995. วารสารวิจัย, คณะศึกษาศาสตร์, มหาวิทยาลัย ศรีนครินทรวิโรฒ, 30 , 86-94.

Rattanavich, S. (2015). Concentrated language encounter approach in practice for global teaching of literacy: Lighthouse strategy implementation. Journal of International Education Studies, 8(7), 21-37. https://doi.org/10.5539/ies.v8n7p21

Rattanavich, S., \& Christie, F. (1993). Developing text-based approaches to the teaching of literacy in Thailand. In G. Gagne, \& A. C. Purves (Eds.), Papers in Mother Tongue Education (pp. 97-110). Münster, NY: Waxmann.

Rattanavich, S., \& Walker, R. F. (1996). Literacy for the developing world. In F. Christie, \& J. Foley (Eds.), Some contemporary themes in literacy research (Vol. 2, pp. 17-45). Münster, NY: Waxmann.

Rotary International. (2009). Global outlook: Focus on literacy. The Rotarian, 187(8), 63-70.

Vygotsky, L. (1978). In M. Cole, V. John-Steiner, S. Scribner, \& E. Souberman (Eds.), Mind in society: The development of higherpsychological processes. Cambridge, MA: Harvard University Press.

Walker, R. F., Rattanavich, S., \& Oller, J. (1992). Teaching all the children to read: Concentrated language encounter techniques. Buckingham, England: Open University Press.

\section{Copyrights}

Copyright for this article is retained by the author(s), with first publication rights granted to the journal.

This is an open-access article distributed under the terms and conditions of the Creative Commons Attribution license (http://creativecommons.org/licenses/by/4.0/). 